Article

\title{
The Role of Indigenous Knowledge in Water Literacy: A Case Study of Semende and Palembang Students
}

\author{
Meilinda 1,*, Khoiron Nazip ${ }^{2}$, Nike Anggraini ${ }^{3}$ and Riyanto ${ }^{4}$ \\ 1 Department of biology education, University of Sriwijaya; meilinda@fkip.unsri.ac.id \\ 2 Department of biology education, University of Sriwijaya; nazipkhoironnazip@yahoo.co.id \\ 3 Department of environment, University of Sriwijaya; anggraini.nike@pps.unsri.ac.id \\ 4 Department of biology education, University of Sriwijaya;riyanto.yanto@fkip.unsri.ac.id \\ * Correspondence: meilinda@fkip.unsri.ac.id; Tel.: +62-81367718552 (M)
}

\begin{abstract}
Water literacy is the ability to feel familiar with and get actively involved in water to face issues about it. This study aims to analyze the water literacy of students who come from areas that have indigenous knowledge related to water conservation and do not have indigenous knowledge but have come from the same province with a similar abundance of water. The samples of this study were 439 people consisting of 184 boys and 255 girls aged 11-18 years from junior and senior high school students in Palembang Municipality and three sub-districts in Muara Enim Regency, namely Semende Darat Laut, Semende Darat Tengah, and Darat Ulu. There were 39 questions for measuring water literacy in the form of a Likert scale (1-5) to measure practical and living literacy with Cronbach alpha values of 0.692 and 0.773 , respectively, and were analyzed with SPSS version 21 through the Mann-Whitney $(\mathrm{u})$ and Cronbach alpha statistical tests. The total alpha was 0.838 . Social literacy was measured in the open-ended question instrument and analyzed descriptively. The results showed that practical water literacy in Palembang was significantly different from Semende's but not with living water literacy. Students' social water literacy in the Semende had two different answer patterns, while, in Palembang, it was more diverse with six different response patterns. Meanwhile, when asked to describe a diagram of the flow of water in nature in Semende, no students think that it is the neglect of customs that results in reduced water in Semende as understood by some students in Palembang who are not involved with these customs.
\end{abstract}

Keywords: Indigenous; knowledge; water literacy; students

\section{Introduction}

Water is a significant need for humans because humans can only live four days without water [1]. Water also has a strong relationship with food security because plants can only produce food if there are adequate water reserves [2]. Lack of water will trigger many problems such as food shortages, the emergence of disease, and other problems in the future. The increase of the world population will increase water consumption for individuals and agriculture as the largest absorbent of water supplies $(60 \%)$ of the total availability of freshwater on earth $[3,4]$. The environmental and conservation education curriculum has convinced many people about environmental problems such as waste recycling, deforestation, global warming, greenhouse gases, and climate change. Unfortunately, the issue of water availability, especially in tropical areas like Indonesia, tends to be neglected. The environmental problems above, especially climate change, will have an impact on the existence of water, and Indonesia will experience water scarcity in 2025 [5].

Lack of attention to water problems, especially in Indonesia, can be seen from the increasing number of rivers and the reduced availability of clean water [6, 7]. Meanwhile, the only research on 
water literacy in Indonesia shows that water literacy among the middle-economic population aged 25-36 years is still low. The data shows water literacy in women is lower than men [8], even though women play a dominant role in household water use policy [9]. The practice of water literacy by children and adolescents is more influenced by habituation and family economy factors [10, 11, 12].

Water literacy is the knowledge about water and its application to daily values and actions consciously [13]. This definition develops into the ability to be familiar with and get actively involved in water to face issues about it $[14,15]$. This development makes water literacy measured based on cognitive, affective, and conative aspects as well as the aspects of practical water literacy, living water literacy, and social water literacy [14].

Several researchers conducted research measuring water literacy in various places such as Covitt et al. [16] at elementary to university students in US, Wood [13] on students and parents in Nottingham UK, Fielding et al. [17] in Australia, Febriani [8] in adults with middle economic levels in Indonesia, He [18] in China, and Onukogu et al. [19] in Nigeria. However, this study only focuses on the behavior and amount of water use in individual and family daily activities (practical and living water literacy), not on social water literacy. There are several studies on the influence of community culture on behavior, such as the study by Sreen et al.[20] regarding the impact of local knowledge on buying behavior for environmentally friendly products and Ma's study [21] reporting the relationship between food, eating behavior, and culture in Chinese society. However, no one has examined the relationship between water literacy and water conservation culture.

Semende is an area located in the province of South Sumatra. Based on research, this area has a water conservation culture in the form of tebat, tambat ayik, and bubus tebat [22]. This indigenous knowledge can make most areas in Semende have an abundance of water so that it is designated as a water conservation area by the Muara Enim regency government. In the same province in South Sumatra, the capital city of Palembang is also an area rich in water. The area has the largest river in Indonesia (the Musi River) with a length of $750 \mathrm{~km}$ (15 km across the Palembang area) with a depth of 8-12 m and a width of 220-313 m. Apart from the Musi River, Palembang also has five other rivers, namely the Ogan, Komering, Keramasan, and Terusan rivers [23]. Even though it is located in the same province, there is no specific indigenous knowledge related to water conservation in the Palembang area.

Analyzing the differences in water literacy at the practical, living, and social levels with junior and senior high school subjects in areas that have and do not have indigenous knowledge related to water conservation can be a reference for developing a water sustainability curriculum based on local community conservation.

\section{Materials and Methods}

\section{Research Area and Population Sample}

In this study, the population of the research targets was junior and senior high school students in Palembang Municipality and three sub-districts in Muara Enim Regency, namely 
Semende Darat Laut, Semende Darat Tengah, and Darat Ulu sub-districts, South Sumatra Province, Indonesia. The selection of Semende and Palembang Municipality was due to several similar characteristics, including (1) both are located in the South Sumatra Province shown in Figure 1 and (2) both are located in areas that have abundant water sources. The difference is that Semende has indigenous knowledge of water conservation in the form of tebat, calak badawan, tambat ayik, and bubus tebat [22]. Because of this indigenous knowledge, this area has water conservation and water tourism. Meanwhile, Palembang is the capital of South Sumatra Province that has many water resources in the form of a large river that divides Palembang into two parts, namely the $u l u$ and the ilir area. The river is called the Musi river that crosses Palembang along $15 \mathrm{~km}$ from a total length of $750 \mathrm{~km}$ with a width of 220-313 $\mathrm{m}$ and a depth of 8-12 m. Besides, there are several other large rivers, such as the Ogan, Komering, Keramasan, and Terusan rivers as well as peat swamp areas. There is no data on the size of the peat swamp areas in Palembang. Thus, the two areas have abundant water resources. There have not been many studies that distinguish water literacy in areas that have abundant water resources. No one has yet examined whether areas of abundant water and indigenous knowledge affect water literacy.

The target population for the Palembang area is 206 junior high school and 201 senior high schools/vocational schools, both public and private schools. Semende only consists of three sub-districts. There are 14 junior high schools and three senior high schools / vocational schools. There is no data obtained on the number of students at DAPODIKNAS (the official website of the Ministry of Education and Culture of the Republic of Indonesia).

In capturing a large number of respondents, several approaches were taken, including using teachers and peers as surveyors. Data was taken randomly via google form from June to September 2020 through volunteer teachers who distributed the forms to their junior high and senior high school students. The instrument used Indonesian and distributed by using google form with the address bit.ly/waterLiteracy, for the sake of safety during the corona epidemic. Due to the difficulty of the internet network, some data is filled in paper and pencil form, especially from the Semende area. From the google form and the paper and pencil form questionnaires that were distributed, there were 729 respondents. Some of the questionnaires from these respondents were discarded for several reasons such as (1) answering on the same scale from the beginning of the question to the end, even though some of the statements presented were conflicting questions; (2) filling in a few statements, while the rest are left blank; (3) several respondents who are not from the research target area. The results of the questionnaire that were analyzed were 439 students aged 11 to 18 years, consisting of 184 boys and 255 girls.

\section{Instrument}

The instrument used to measure water literacy was designed by modifying the framework developed by Otaki et al. [14]. There are three parts of water literacy, namely practical, living, and social water literacy. Water literacy practice is the practice of knowledge and the use of water in everyday life on an individual scale, such as being able to know the basic requirements of clean water for consumption and individuals' sanitation, such as drinking and washing hands. Living water literacy is an effort to get the best quality and quantity water for the scale of the family's interests, such as collecting and utilizing rainwater, setting the distance of septic tank and clean water wells, and selecting water sources for family consumption. 
Social water literacy refers to the willingness to take the right solution regarding the availability, management, and use of water in the community. The framework from Otaki et al. [14] is combined with the measurement of cognition, affection, and conation in practical and living water literacy based on the tripartite theory developed by Ajzen [24]. The theory is often used as a guide in making literacy instruments such as environmental literacy instruments, science, energy, and so forth.

The instrument validation step used the deVellis [25] question development step, validated by five environmental experts whose validation results were valid. The validity questions were tested for the reliability level of 435 students. The data on practical literacy consisted of 17 questions, consisting of seven cognition questions, seven affection questions, and three conation questions having an overall Cronbach alpha reliability value of 0.692 . Living literacy consisted of 22 problems with eight questions of cognition, six questions of affection, and eight questions of conation have a reliability value of 0.773 . The overall reliability value is 0.838 . Meanwhile, social water literacy used the socio-hydrology issue framework developed by Forbes et al. [26] using local issues from Semende and Palembang. The example questions can be seen in Table 1.

Table 1. The Example of water literacy question

\begin{tabular}{crl}
\hline \multicolumn{1}{c}{ Practical water literacy } & \multicolumn{1}{c}{ Living water literacy } \\
\hline If served bottled mineral water, I will & Our family has a rainwater reservoir so the water can be used for \\
drink it until it runs out & household purposes \\
1. Strongly disagree & $\begin{array}{l}\text { 1. Strongly disagree } \\
\text { 2. Disagree }\end{array}$ \\
3. Neutral & $\begin{array}{l}\text { 2. Disagree } \\
\text { 4. Agree }\end{array}$ \\
5. Strongly agree & $\begin{array}{l}\text { 3. Agree } \\
\end{array}$ \\
\hline
\end{tabular}

Semende is a mountainous area in Muara Enim Regency that has the Tunggu Tubang custom. Tunggu Tubang custom is the obligation to maintain a family legacy of rice fields and to ensure the amount of rice production. Several habits take place from generation to generation, such as maintaining tebat which is a springs reservoir for irrigating rice fields and raising fish, protecting forests for preserving tebat springs or for irrigating rice fields called Hulu Ayek Forest, using springs or ayik ntup-ntup as household water consumption, and tambat ayik as an effort to utilize the flowing water as much as possible before it is returned to nature, such as from the tebat to the rice fields, to the fish pond, the rice fields, then into the river. Based on the above discourse, answer the following questions:

1. Of the habits related to water conservation mentioned above, which part is related to:
a. Springs protection
b. High-quality drinking water usage
c. Water reuse

2. If the people start to ignore the custom of tambat ayik, do you think this will disturb the availability of water in the area? Please explain your answer along with the reason

\section{Participant sample}

Overall, there were 439 students aged 12 to 18 years involved who came from two regions, namely 365 students from Palembang and 74 students from Semende. Those 439 students consisted of 255 girls and 184 boys. The Semende community is a rural community with a low level of 
economy and education, but these areas have indigenous knowledge of water conservation. Because of this indigenous knowledge, water conservation built in this area, even the existing water sources can be a source of electrical energy and a tourist area. Meanwhile, Palembang is the capital of South Sumatra Province that has a lot of water resources and swamp areas so that Palembang has an abundance of water resources similar to the Semende area.

\section{Data and Analysis}

For analyzing students' responses recorded on google form and survey sheets, the researchers used Microsoft Excel. The researchers converted student responses into numeric scores. The scale items of practical water literacy and living water literacy on the Likert scale were 1 for strongly disagree to a score of 5 for strongly agree. Participants' responses to each scale for practical water literacy and living water literacy were analyzed using the SPSS version 21 program with the Mann-Whitney test by comparing samples from Semende and Palembang on practical and living water literacy indicators then looking for the level of significance using size effect while for social water literacy analyzed descriptively.

\section{Results}

This section presents the findings of practical and living water literacy values statistically, and social water literacy descriptively in Semende and Palembang.

\subsection{Practical water literacy}

Practical water literacy is the practice of individual water literacy, based on the results of the validation and reliability test. This section consisted of 17 questions, each of which consists of seven cognitive questions, five affective questions, and five conative questions. Of the 17 questions when tested with the Mann Whitney $(\mathrm{u})$ test, the value was 0.000 that indicates that there is a significant difference between the groups of students from Palembang and Semende on the practical water literacy indicators with Palembang students having a better practical value of water literacy as in Table 2.

Table 2. Mann Whitney $(u)$ test of practical water literacy indicators

\begin{tabular}{lr}
\hline & Practical Water Literacy Indicators \\
\hline Mann-Whitney $(u)$ & 8409.500 \\
\hline Asymp. Sig. (2-tailed) & 0.000 \\
\hline
\end{tabular}

a. Grouping Variable: Palembang-Semende

The overall data is significant, specifically in numbers $8,11,12$, and 16 , which are the affection or structure of preference for students' practical water literacy indicators. The four questions can be seen in Table 3. 
Table 3. Statement details on practical water literacy indicators

\begin{tabular}{|c|c|c|}
\hline Number & Statement & Information \\
\hline 8 & I prefer drinking well-boiled water to unsecured refill gallon water. & Affection \\
\hline 11 & $\begin{array}{l}\text { I prefer to bathe using water from my own } \\
\text { well since I feel more satisfied. }\end{array}$ & Affection \\
\hline 12 & I prefer to bathe in the river or pool because I feel more satisfied with the water. & Affection \\
\hline 16 & When served bottled mineral water, I will drink it until it runs out. & Conation \\
\hline
\end{tabular}

For statement 8 , the data obtained shows that although the dominant group agrees and strongly agrees, the percentage of students from Semende (77\%) is greater than Palembang (56\%). For statement 11, data shows that there were $84 \%$ of 74 students who like and want to bathe using their well water because it is freer, while only 15\% of students in Palembang like to bathe using their well water. Well water in family houses in Palembang is generally covered with cement and taken with a water pump machine to be accommodated in a limited tub. The amount of water that can be used is also limited so that it cannot be used for bathing as much. The average Likert scale is on the conation indicator practical living on the question of "when I take a shower, I spend more than 20 minutes", students from Palembang answered on a scale of 1-3 with a mean of 2.9, while Semende's average answered on a scale of 3-4 with a mean of 3.4, even though when it tested by the test Mann Whitney was not significantly different.

Statement 12 about bathing in a swimming pool or a river, the data shows $68 \%$ of students prefer to take a bath in the river or a pool. In Palembang, only 31\% like to take a bath in the pool since the rivers in Palembang are not suitable or too dangerous for swimming. Moreover, people should pay if they want to swim in Palembang.

For the conation in statement 16 , it shows that $26 \%$ of students in Semende and $41 \%$ of students in Palembang agreed and strongly agreed with the statement number 16. It means that both students from Semende and Palembang were not used to drink mineral water that was served until it ran out.

\subsection{Living water literacy}

Living water literacy means the ability to use water wisely in the home and backyard social spaces as well as ensuring a quality water supply so that everyone has enough water for a healthy life. Based on the results of the validity and reliability test, 22 questions were consisting of eight cognitive questions, six affective questions, and eight conative questions. Of the 22 questions when tested by the Mann Whitney $(\mathrm{u})$ test, the value was 0.347 which indicated that there was no significant difference between the groups of students from Palembang and Semende on the indicators of living water literacy as in Table 4.

Table 4. Mann Whitney test $(u)$ living water literacy indicators

\begin{tabular}{cc}
\hline & Living Water Literacy Indicators \\
\hline Mann-Whitney $(u)$ & 12570.500 \\
Asymp. Sig. (2-tailed) & 0.347 \\
\hline
\end{tabular}

a. Grouping Variable: Semende-Palembang 
Although they are not significantly different when tested for the level of significance on each item, the significant difference lies in questions $25,31,32,38$, and 40 . The six items can be seen in Table 5.

Table 5. Statements of living water literacy indicators that have a significant difference

\begin{tabular}{lll}
\hline Number & \multicolumn{1}{c}{ Statement } & Information \\
\hline 25 & Rainwater can be directly used for consumption & Cognition \\
31 & Our family likes to save water to save money & Affection \\
32 & Our family prefers to save water because they understand that the amount of waterAffection \\
38 & consumption is limited & Conation \\
40 & Our family uses a dipper to bathe & Conation \\
\hline
\end{tabular}

Statement 25 was agreed by more students from Semende with a percentage of $41 \%$ while in Palembang only $25 \%$. The data shows that students from Palembang understand that they cannot consume the rainwater directly, while students from Semende often play and drink rainwater straightly when it comes down to earth.

Numbers 31 and 32 are statements that are contradictory to living water literacy. Statement number 31 is a student affection for living water literacy influenced by financial factors, while number 32 is an affection for living water literacy that is influenced by knowledge. From the survey in the number $31,64 \%$ of students from Semende and $7.7 \%$ of students from Palembang. Meanwhile, in number 32, it is about 32, 59\% of students from Semende, and 70\% of students from Palembang. The data indicates that apart from knowledge, the economy is a factor in frugality in water consumption in groups of Semende students.

In question 38, the habit of bathing in the family using a dipper as part of living water literacy, the data shows that $78 \%$ of students from Semende, and $84 \%$ of students from Palembang. The lower percentage of the use of a dipper than Semende students does not mean they do not like using a dipper but because of environmental factors that make them prefer to bathe in a bath, pool, fountain, or river. Meanwhile, in the $40^{\text {th }}$ statement, $74 \%$ of students from Semende and $89 \%$ of students from Palembang had parents who reminded their children to save water.

\subsection{Social water literacy}

Social water literacy refers to the willingness to understand and make reasonable decisions for the community about water usage. To have good social literacy, one must have the ability to understand about water resources, water treatment, water flow, and wastewater treatment. Although practical and living water literacy is literacy in everyday life, social water literacy has a broader perspective, such as eutrophication. Eutrophication is the abundance of chemical nutrients caused by nitrogen and phosphorus being discharged into water from waste, and the water cycle in the environment [14].

In the matter of social water literacy, combined with the social context of the Semende and Palembang areas, the first question is related to the role of indigenous knowledge in the form of Ulu Ayek Forest, tebat, ayik ntup-ntup, and tambat ayik in water conservation in the Semende region. Although this indigenous knowledge is not officially taught in schools, most students from Semende 
$(82 \%)$ understand the role of indigenous knowledge in water conservation such as tebat as part of efforts to maintain water resources, ayik ntup-ntup as an effort to maintain quality drinking water, and tambat ayik as water reuse cycle efforts. Even so, some students still think that ignoring indigenous knowledge will not disturb the existence of water in Semende. The presence of abundant water in Semende is caused by 1) the position of Semende in the mountains and hills as stated in Figure 1.a; 2) there is forest as in Figure I.b; 3) the water in Semende flows swiftly and will not decrease as in Figure 1.c; 4) water needs have been fulfilled from the flow of PAM (Drinking Water Company) as in the student's answer quote on google form in Figure 1.d.

As additional information, what is meant by PAM water in the Semende area is not from state companies providing water but the water that is piped from house to house. Figure 1d shows that water comes from mountain springs that are specifically for consumption which is called ayik ntup-ntup.

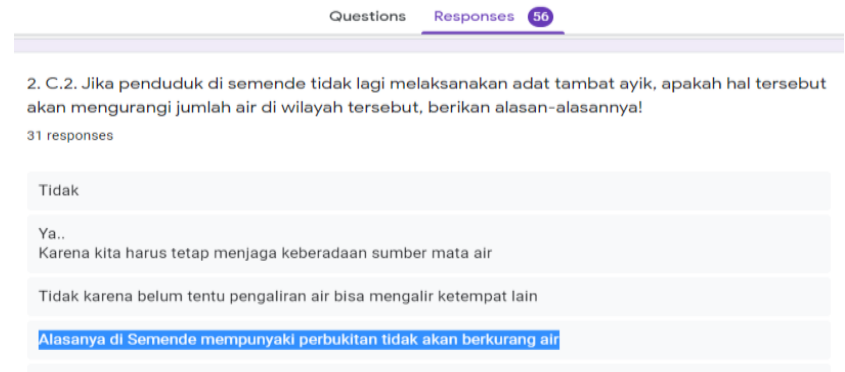

(a)

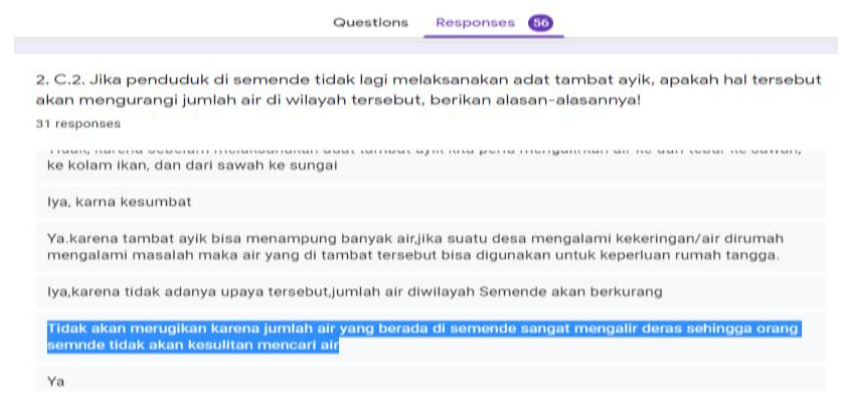

(c)

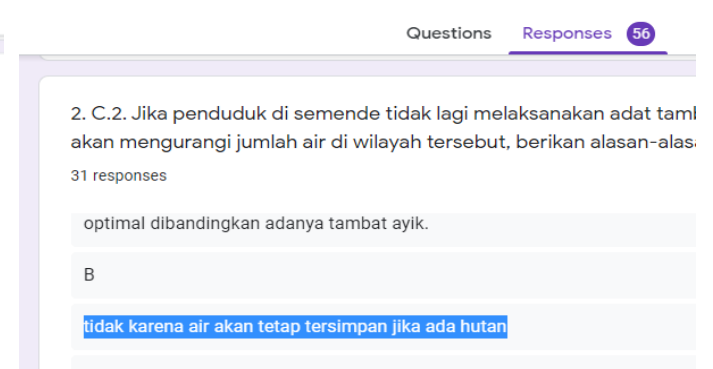

(b)

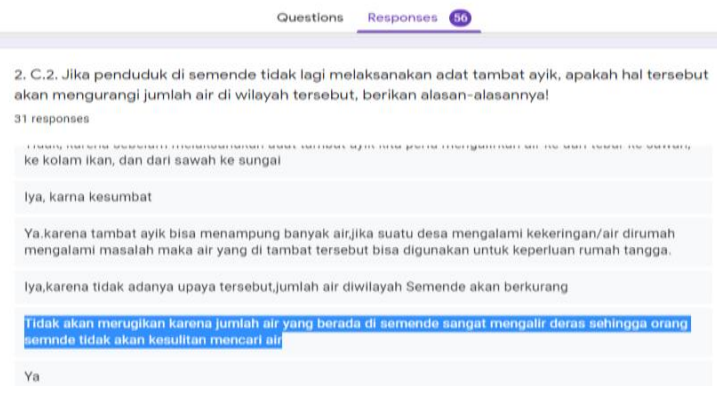

(d)

Figure 1. Several reasons for the students' statements about ignoring indigenous knowledge will not affect the existence of the amount of water in Semende: (a)a Semende is a hilly area so that the water will not decrease; (b)Water will still be stored if there is a forest; (c) The amount of water will not decrease because the amount of water in Semende flows swiftly; (d) Because there is PAM Water

In social water literacy, with the context of problems in Palembang, such as neglecting the existence of retention ponds, covering the land with roads or buildings, and even dumping garbage into the water, students from Semende can answer well by stating that this will disturb the existence of river water and clean water sources in the city of Palembang.

The students who came from Palembang had a different pattern with the answers from Semende students. Semende students have two answer patterns, namely: 1) realizing that the existence of indigenous knowledge is a logical effort to conserve water in the area and; 2) there is no relationship between indigenous knowledge and the presence of water in the area because of the large amount of water in Semende because of its mountainous areas. Meanwhile, students from 
Palembang Municipality have more varied answers. There are six patterns of responses from students in Palembang regarding social water literacy in the Semende, namely: 1) the amount of water is limited because it is significant not to ignore customs. After all, the customs in Semende can scientifically maintain the existence of water in nature $(31.2 \%) ; 2)$ customs is significant to be preserved because it is ancestral heritage so that neglect of customs will harm society and the environment (20\%); 3) without reason (18.4\%); 4) disregard for customs will not have any influence on the presence of water in the environment because there is a lot of water in nature $(16 \%) ; 5)$ the Semende area will never experience drought because it is in a mountainous area and there are many trees $(6.8 \%) ; 6)$ The existence of water has nothing to do with customs but depends on the weather and rain $(4.5 \%) ; 7)$ the implementation of customs will affect the existence of water because the customs are closely related to water conservation (4.5\%).

The statement that the water in Semende will not decrease because it is in the mountainous area and the statement that neglecting the custom of the tambak ayik or other indigenous knowledge will disturb the existence of water in Semende as in Figure 2.

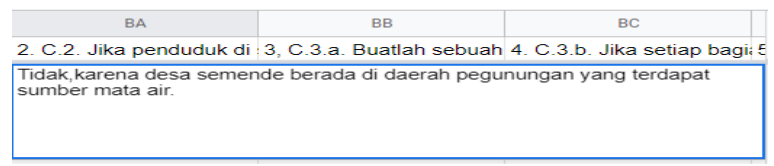

(a)

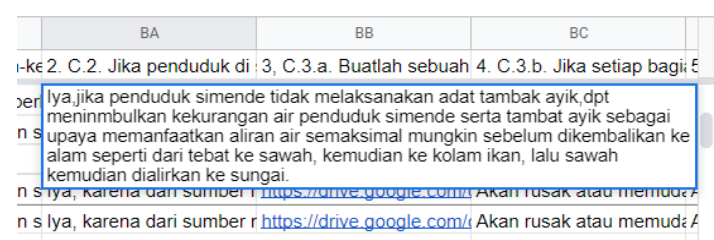

(c)

Tidak, karena yg mempengaruhi pengurangan jumlah air adalah pemeliharaan hutan hulu ayek,
Ya.pembagian air akan tidak merata

\begin{tabular}{l|}
\hline Tidak mengurangi karena daerahnya dekat pergunungan \\
Bisa, \\
nn likn tidnı dirnusnt mnken sumhnr nir himn hilnnn
\end{tabular}

(b)

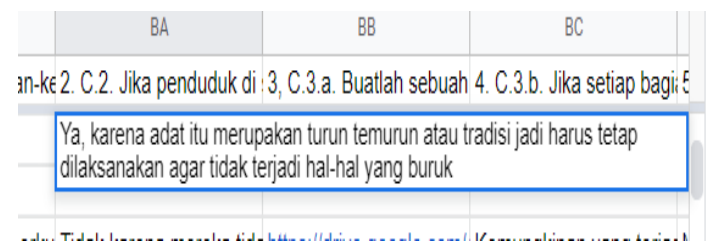

(d)

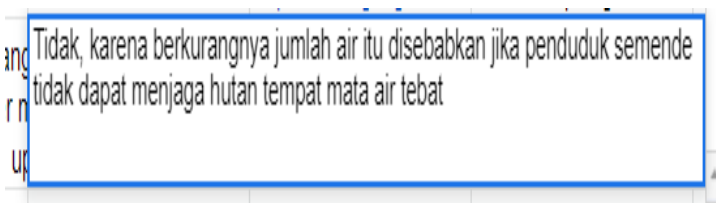

(f)

Figure 2. Palembang Students' answers about the relationship between neglecting the Semende customs and the existence of water in the area. (a) The Semende area is in a mountainous area so there are many springs;

(b) Not reduce the amount of water because the area is near the mountains.; (c)If Semende people do not practice their customs, it will cause water shortages; (d) Because custom is hereditary or tradition so it must be carried out so that no bad things happen; (e) Reducing the amount of water due to not maintained Ulu Ayek Forest.; (f)The water will not decrease unless the forest where the tebat water is not maintained

The answer of Palembang student, which stated that the neglecting the customs had an impact on the existence of water since the tradition was an ancestral heritage, did not exist in the Semende student statements. The absence of statements regarding customary violations that reduced water due to indigenous knowledge carried out by the Semende community such as tebat, Ulu Ayek Forest, tambak ayik, and ntup-ntup, has been part of daily community habits without mixing with an illogical 
understanding of rituals like students from Semende answer in figure 3. There is an illogical understanding, such as there are watchmen included in the indigenous knowledge of calak badawan, namely the taboo culture of throwing trash and polluting springs by throwing garbage, bathing for menstruating women, and defecating [22]. Those also make students from Semende able to answer questions about social water literacy in the context in Palembang.

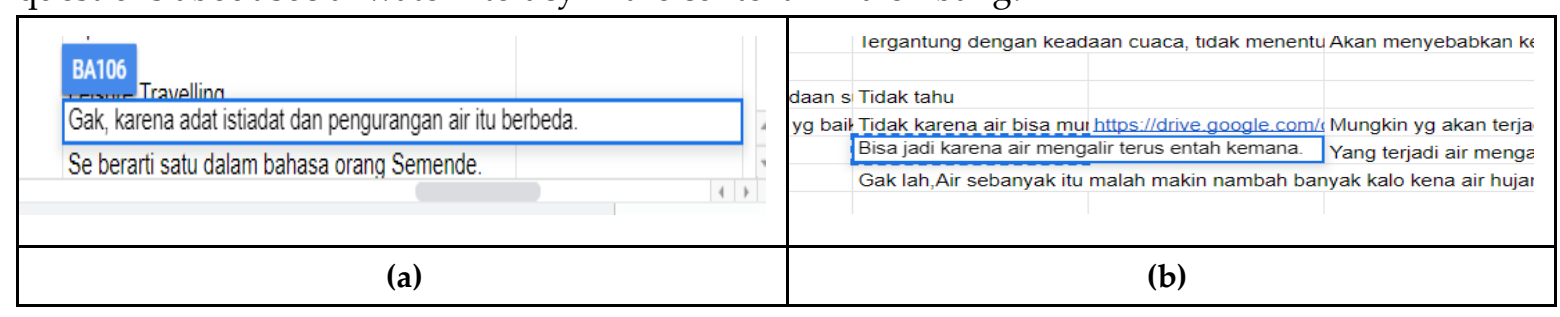

Figure 3. Student answer from Semende about relation between customs dan water scarcity: (a) There is no relation between customs and water scarcity; (b)There is no relation between customs and water scarcity because water still flows out of nowhere.

However, some students answered with the following statements: 1) water will continue to exist and flow everywhere; 2) water will always be there, especially if the rainy season will be even more; 3) water can appear everywhere; 4) water resources will not decrease, because the water never runs out; so forth. Some students from Palembang and Semende realized that the amount of water was limited in nature, so that is necessary to return water to nature so that it could be used wisely. However, they failed to relate this to the water cycle when asked to describe the existing water flows in the context of the Semende as shown in Figure 4.

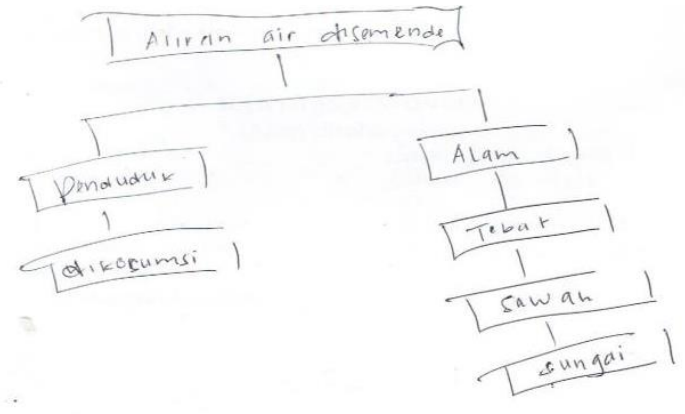

(a)

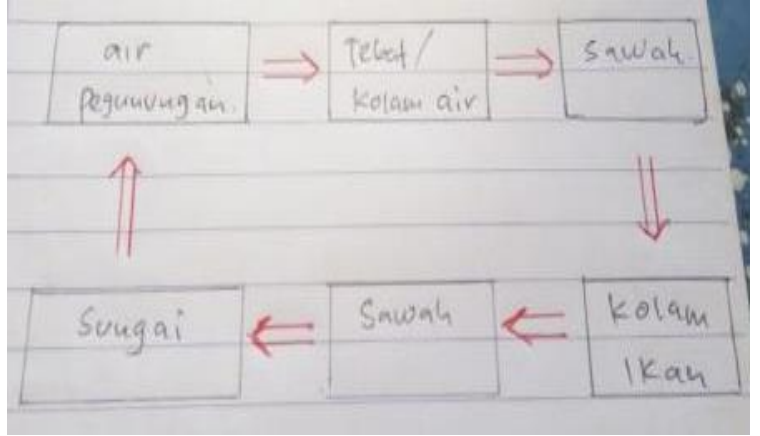

(b)

Figure 4. Students' diagram of the water cycle (a) From Semende; (b) From Palembang

From Figure 4.a, the flow diagram in Semende starts from a spring that is divided into two types, namely tebat water and natural water (ayik ntup-ntup). The water from the tebat flows into the rice fields and then into the river. The residents directly used springs water for consumption, but the process of water flow after consumption does not show a cycle. While the diagrams from Palembang students are in the form of cycles, it is not seen how the process from the river returns to a spring in the mountains. It does not appear that the water cycle also involves the processes that occur in the human body.

\section{Discussion}

Education about water in primary and secondary schools in Indonesia has not become a special concern. This has resulted in the spread of content about water in several fields such as 
Biology, Physics, and Chemistry without directly linking it to conditions in nature even though water scarcity will become a big issue by 2025 in Indonesia [5]. Inadequate attention to water is most likely caused by the condition that people in some cities still have sufficient water and the existing shortages can be covered by water supply from other places through PDAM (Regional Drinking Water Company).

On the other hand, Indonesia with various conditions has much indigenous knowledge related to water conservation such as Pronoto Wongso, Nyabuk Gunung in the island of Java, Pahomba in East Nusa Tenggara, Subak in Bali, Maccera Tasi in South Sulawesi [27], Tuk Busy in Yogyakarta (28), and water in the Semende area [22]. However, of the many conservation areas about water and the environment in Indonesia, no one has measured the water science literacy of the younger generation, so it is not known what impact indigenous knowledge has on the younger generation.

From the results of the study, it was found that the water literacy of Semende students on practical water literacy indicators was significantly different compared to Palembang students, especially in affective aspects such as preferring to consume well water than gallons water and preferring to bathe in tub water or rivers. The difference of practical water literacy between students in Semende and Palembang is more influenced by the environment in which they grow up, as suggested by Leveque and Burns [29] and Qian [30]. They say that a person's perception of water is influenced by the habits around them as they grow and develop.

Semende is a mountainous area with many rivers and ancestral heritage ponds. Thus, bathing in the river and tebat has become a daily habit. It is different from students from Palembang, although Palembang was once called as "Venice from the East" because of its many rivers and water canals, they rarely swim in rivers or ponds because of the river conditions are not safe for children and teenagers to swim. Meanwhile, to swim in the pool they have to pay quite a fortune. So, it can be concluded that the practical water literacy of children and adolescents towards water is not influenced by economic conditions like adults [13], but is more influenced by the level of satisfaction in using water such as the frequency of water use for bathing and swimming [31]. This is following the findings of the study in the form of the number of Palembang students who bathed less than 20 minutes compared to Semende students. Living water literacy is an effort to get the best quality and quantity water for the scale of family interests, such as storage and utilization of rainwater, setting the distance of septic tanks and clean water wells, and selecting water sources for family consumption [14]. The family framework for making decisions in living water literacy does not depend on the students who are the respondent of this research. From the results of the questionnaire, it was found that the decisions related to water use in the family were in the hands of the parents, even 20\% were with mothers both in Palembang and Semende.

Adults generally know what they have to do to conserve water. However, the research of Owen et al. [10] stated that these adults do not know the reasons behind their behaviors. Based on further research, it is stated that water conservation behavior in adults is often carried out without reasons but only adapted from the surrounding environment. Although the study did not study the living water literacy of parents, based on the results of the questionnaire, it was found that $74 \%$ of students from Semende and $89 \%$ of students from Palembang had parents who reminded children to save water. Economic factors are another factor to save water besides the knowledge of Semende students. 
At the educational level, parents of Palembang students have better formal education than parents of Semende students. This can be seen from the number of parents who graduated from senior high school $36.4 \%$ and bachelor only $7.4 \%$. The rest even did not go to school. Meanwhile, parents from Palembang, 51.8\% graduated from senior high school, and $8.6 \%$ bachelor graduate. This contradicts the findings of several studies which state that education levels affect water literacy in children and adults [11,13,31]. The researchers assume that it is not the level of education that affects water literacy but the knowledge they have about water. Even though Semende is a rural area that is far from technology and information and has low levels of education, indigenous knowledge and storytelling are tools that shape students' perceptions of the environment [32]. Masuku [33] states that traditional societies, myths, taboos, and local wisdom are effective educational tools to educate their people.

Examples of storytelling and indigenous knowledge that can educate the Semende community about water are storytelling about mountain springs which in the local language is called ayik ntup-ntup, taboo culture in the form of a prohibition against polluting water sources in tebat (calak Badawan), and community obligations of indigenous peoples to protect the forest where the water source is (Ulu Ayek Forest) [22,34,35]. Ayik ntup-ntup is water from mountain springs that residents use for consumption water such as washing, cooking, and drinking water. In the understanding of the Semende community, ayik ntup-ntup is special water because it comes out of the ground and will not become cloudy due to heavy rain. This water is believed by the community to be water brought by Puyang Lebi, the ancestor of the village founder, from a bottle of zam-zam water in the holy land of Mecca. This belief has been passed down from generation to generation through the ayik ntup-ntup tales [34]. Stories or storytelling are the basis of all human learning and teaching processes around the world [36]. According to Masuku [33], several traditional communities use storytelling, taboo culture, myths, and other traditional cultures as an effort to pass on knowledge about nature to the next generation such as the people in Kenya [37] and Ghana [38].

An interesting finding from this research is that even though the informal education that students get from the community and parents is in the form of storytelling and taboo culture, they do not see customs as things that must be obeyed solely so that disasters do not occur, such as understanding students outside Semende's social water literacy in Semende (Figures 2c and 2d). This is because these customs can be rationalized in the institution of meraje anak belai as part of fulfilling the needs of residents to irrigate fields inherited from their ancestors that cannot be traded $[35,39,40]$.

In the social water literacy about the role of indigenous knowledge on water conservation in the Semende, it was found that the same answer pattern was found between some Palembang and Semende students, namely that neglecting indigenous knowledge would not interfere with the existence of water due to the abundance of water in Semende. The abundant amount of water is caused by the position of the Semende in mountainous areas as one of the statements in Figure 1.a. This misconception about the abundance of water is found in many places such as the study of Barrutia et al. [41]. This wrong conception is closely related to the conception of the water cycle. Students think that water is plentiful because it continues to fall on the surface of the earth even when it rains, it becomes abundant and causes flooding (Figure 3.b). This data is supported by the current water cycle scheme that the students describe in Figures a and $b$. 
When students are asked to draw a water flow diagram in the context of the Semende area, although they can describe the beginning of the emergence of water sources, the diagram does not describe the cycle. Yet according to Wheeler [42], knowledge about the water cycle is a basic knowledge that students must have. Students' incomprehension and even misconceptions about the water cycle were also found in many studies conducted by Cardak [43], and Assaraf \& Orion [44]. According to several studies, several things that make it difficult for students to understand water in everyday contexts as a system that has a cycle even though they have learned about the water cycle at school include: 1) the difficulty of understanding the concept of evaporation and transpiration in the water cycle that makes water move from earth to atmosphere and vice versa; 2 ) do not understand the context of the system in water [44]; 3) the lacks of thinking skill systems. Even though a thinking skill system is a student's frame of mind to solve problems related to water $[45,46,47]$.

This finding can be important information for researchers and educators that local indigenous knowledge is the knowledge that cannot be ignored in the development of environmental literacy learning, especially water literacy. Thus, it is necessary to detect indigenous knowledge and make it a starting point for the development of environmental literacy learning.

Authors should discuss the results and how they can be interpreted in perspective of previous studies and of the working hypotheses. The findings and their implications should be discussed in the broadest context possible. Future research directions may also be highlighted.

\section{Conclusions}

Indigenous knowledge is education that is passed down from generation to generation. Even though students from Semende are in an environment that has limited information and parents with low formal education, the indigenous knowledge possessed by the Semende community makes the environmental literacy owned by students not significantly different, especially on indicators of living water literacy and social water literacy.

Supplementary Materials: The following are available online at www.mdpi.com/xxx/s1, Figure S1: title, Table S1: title, Video S1: title.

Author Contributions: For research articles with several authors, a short paragraph specifying their individual contributions must be provided. The following statements should be used "Conceptualization, Meilinda and Nike Anggraini; methodology, Khoiron Nazip and Riyanto; validation, Meilinda, Khoiron Nazip, Nike Anggraini; formal analysis, Meilinda; investigation, Meilinda, Khoiron Nazip, Riyanto; resources, X.X.; data curation, Meilinda.; writing-original draft preparation, Meilinda; writing-review and editing, Khoiron Nazip, Nike Anggaraini, Riyanto. All authors have read and agreed to the published version of the manuscript.", please turn to the CRediT taxonomy for the term explanation. Authorship must be limited to those who have contributed substantially to the work reported.

Funding: This research received no external funding

Acknowledgments: Thank you for all Students from Semende and Palembang wich is contrbution to this research.

Conflicts of Interest: The authors declare no conflict of interest.

\section{References}

1. Towell, C., The Survival Handbook: Essential Skills for Outdoor Adventure. DK Pub. 2009

2. Maréchaux, I., Bartlett, M.K., Sack, L., Baraloto, C., Engel, J., Joetzjer, E. and Chave, J. Drought tolerance as predicted by leaf water potential at turgor loss point varies strongly across species within an Amazonian forest. Functional Ecology 2015, 29(10), pp.1268-1277.

3. Vickers, A., 2001. Handbook of Water Use and Conservation. Waterplow Press, Amherst, MA, 2001 
4. Harlan, S.L., Yabiku, S.T., Larsen, L. and Brazel, A.J., 2009. Household water consumption in an arid city: affluence, affordance, and attitudes. Society and Natural Resources 2009, 22(8), pp.691-709.

5. Royyani, Hastri. (2017). Climate Change Impacts, Clean Water Crisis in Indonesia. https://www.itb.ac.id/news/3177.xhtml. Access date 3 September 2020.

6. Mawardi, I. Kerusakan daerah aliran sungai dan penurunan daya dukung sumberdaya air di pulau jawa serta upaya penanganannya. Jurnal Hidrosfir Indonesia 2010, 5(2).

7. Amalia, B. I., \& Sugiri, A. Ketersediaan air bersih dan perubahan iklim: Studi krisis air di Kedungkarang Kabupaten Demak. Teknik PWK (Perencanaan Wilayah Kota) 2014, 3(2), 295-302.

8. Febriani, A. (2017). Water Literacy in Developing Country-A case study for Indonesia. Master's Degree, Lund University, Lund Sweden, 2017

9. Wutich, A., Rosinger, A. Y., Stoler, J., Jepson, W., \& Brewis, A. Measuring human water needs. American Journal of Human Biology 2020, 32(1), e23350.

10. Owen-Smith, N. Introduction to modeling in wildlife and resource conservation. John Wiley \& Sons. New York, 2009

11. Spaargaren, G. (2004) Sustainable consumption: a theoretical and environmental policy perspective, in Southerton, D., H. Chappells and B. Van Vliet (Eds) Sustainable Consumption: The implications of changing infrastructures of provision, Cheltenham: Edward Elgar. 2004. pp.15-31

12. Martens, L., Southerton, D., \& Scott, S. Bringing children (and parents) into the sociology of consumption: Towards a theoretical and empirical agenda. Journal of consumer culture 2004, 4(2), 155-182.

13. Wood, G. V. Water literacy and citizenship: education for sustainable domestic water use in the East Midlands. Doctoral dissertation, University of Nottingham, Nottingham UK. July 2014

14. Otaki, Y., Sakura, O., \& Otaki, M. (2015). Advocating water literacy. Mahasarakham International Journal of Engineering Technology 2015, 1(1), 36-40.

15. McGuinness, S. L., O’Toole, J., Barker, S. F., Forbes, A. B., Boving, T. B., Giriyan, A., ... \& Leder, K. Household Water Storage Management, Hygiene Practices, and Associated Drinking Water Quality in Rural India. Environmental Science \& Technology 2020, 54(8), 4963-4973.

16. Covitt, B. A., Gunckel, K. L., \& Anderson, C. W. Students' developing understanding of water in environmental systems. The Journal of Environmental Education 2009, 40(3), 37-51.

17. Fielding, K., Karnadewi, F., Mitchell, E., \& Newton, F. A National Survey of Australians' Water Literacy and Water-related Attitudes. 2015. https://research.monash.edu/en/publications/a-national-survey-of-australians-water-literacy-and-water-r elated. Access date 24 Agustus 2020

18. He, H. S. (2018). Construction of the index system of water literacy and application in a case study of four Chinese communities. Journal of Discrete Mathematical Sciences and Cryptography, 21(2), 485-491.

19. Onukogu, S. C.; Ugwuanyi, P. N.; \& Adiaha, M. S. Level of awareness, perception and attitude of senior secondary school students towards water in Chanchanga Local Government Area, Niger state. World Scientific News 2018, 105, 74-98.

20. Sreen, N., Purbey, S., \& Sadarangani, P. Impact of culture, behavior and gender on green purchase intention. Journal of Retailing and Consumer Services 2018, 41, 177-189.

21. Ma, G. Food, eating behavior, and culture in Chinese society. Journal of Ethnic Foods 2015, 2(4), 195-199.

22. Meilinda ;Nazip, K.; Riyanto. Indigenous knoewledge of Besemah-Semende's people on water conservation resources. IJSED state of publication (accepted)

23. Suryani, A. S. Persepsi Masyarakat dalam Pemanfaatan Air Bersih (Studi Kasus Masyarakat Pinggir Sungai di Palembang). Jurnal Aspirasi 2016, 7(1), 33-48.

24. Ajzen, I. The theory of planned behavior. Organizational behavior and human decision processes 1991, 50(2), 179-211.

25. DeVellis, R. F. Scale development: Theory and applications. Sage publications. California USA, 2016; Volume 26

26. Forbes, C. T., Brozović, N., Franz, T. E., Lally, D. E., \& Petitt, D. N. Water in Society: An interdisciplinary course to support undergraduate students' water literacy 2018. Journal of College Science Teaching 2018, 48(1), 36-42. 
27. Maridi, M. (2015). Mengangkat Budaya dan Kearifan Lokal dalam Sistem Konservasi Tanah dan Air. In Proceeding Biology Education Conference: Biology, Science, Enviromental, and Learning, Universitas Sebelas Maret, Indonesia, 1 November 2015, Universitas Sebelas Maret. 2015; Vol. 12, No. 1, pp. 20-39

28. Triastianti, R. D., Nasirudin, N., Sukirno, S., \& Warsiyah, W. Konservasi sumber daya air dan lingkungan melaluhi kearifan lokal di desa margodadi kecamatan seyegan kabupaten sleman yogyakarta. Jurnal Kawistara 2017, 7(3), 285-296.

29. Levêque, J. G., \& Burns, R. C. (2018). Drinking water in West Virginia (USA): tap water or bottled water-what is the right choice for college students?. Journal of water and health, 16(5), 827-838.

30. Qian, N. Bottled water or tap water? A comparative study of drinking water choices on university campuses. Water 2018, 10(1), 59.

31. Dean, A. J., Fielding, K. S., \& Newton, F. J. Community knowledge about water: who has better knowledge and is this associated with water-related behaviors and support for water-related policies?. PloS one 2016, 11(7), e0159063.

32. Stables, A. \& Bishop, K. Weak and strong conceptions of environmental literacy: implications for environmental education, Environnzental Education Research 2001, 7, pp. 00-00.

33. Masuku, L. S. The role of indigenous knowledge in/for environmental education: The case of a Nguni story in the Schools Water Action Project, Doctoral dissertation, Rhodes University. January 1999

34. Aliana, Z. A. Ratnawati, L.; Rony M.M.S.; Suan A.B. Struktur sastra lisan Semende. Pusat Pembinaan dan Pengembangan Bahasa, Departemen Pendidikan Nasional. Jakarta, Indonesia, 2000; pp. 57-58

35. Martin, E. D. Suharjito, D. Darusman, S. Sunito, and B. Winarno, Tunggu Tubang and Ulu Ayek: Social Mechanism of Sustainable Protected Forest Management, Jurnal Manajemen Hutan Tropika 2016, vol. 22, no. 2, pp 85-93.

36. Cajete, G. Look to the mountain: An ecology of indigenous education. Kivaki Press, Montana Colorado, USA, 1994

37. Chemhuru, M., \& Masaka, D. Taboos as sources of Shona people's environmental ethics. Journal of Sustainable Development in Africa 2010, 12(7), 121-133.

38. Opoku, K. Forest Governance in Ghana: An NGO Perspective. FERN, The Netherlands. 2006

39. Martin, D. E.; Suharjito, D.; Darusman, S.; Sunito; \& Winarno, B.; Traditional Institution for Forest Conservation within a Changing Community: Insight from the Case of Upland South Sumatra", Komunitas: International Journal of Indonesian Society and Culture 2016, Vol.8, No.2, pp 236-249.

40. A.R. Yenrizal, R. Agus, B. Atwar, and I. Johan, Makna simbolik sawah di masyarakat pedesaan tinjauan komuniasi lingkungan pada masyarakat Semende Darat Tengah Kabupaten Muara Enim-Sumatera Selatan, Jurnal Kawistara 2015, vol 5, no. 3, pp 221-328

41. Barrutia, O., Ruíz-González, A., Villarroel, J. D., \& Díez, J. R. Primary and Secondary Students' Understanding of the Rainfall Phenomenon and Related Water Systems: a Comparative Study of Two Methodological Approaches. Research in Science Education 2019, 1-22.

42. Wheeler, S., Zuo, A., \& Bjornlund, H. (2013). Farmers' climate change beliefs and adaptation strategies for a water scarce future in Australia. Global Environmental Change 2013, 23(2), 537-547.

43. Cardak, O. Science students' misconceptions of the water cycle according to their drawings. Journal of Applied Sciences 2009, 9(5), 865-873.

44. Ben-zvi-Assarf, O., \& Orion, N. A study of junior high students' perceptions of the water cycle. Journal of Geoscience Education 2005, 53(4), 366-373.

45. Hmelo-Silver, C.; Jordan, R.; Eberbach, C.; Sinha, S. Systems learning with a conceptual representation: A quasi-experimental study. Instr. Sci. 2016, 45, 53-72.

46. Yoon, S.A.; Hmelo-Silver, C. Introduction to special issue: Models and tools for systems learning and instruction. Instr. Sci. 2017, 45, 1-4.

47. Lally, D.; Forbes, C.T. Modelling water systems in an introductory undergraduate course: Students' use and evaluation of data-driven, computer-based models. Int. J. Sci. Educ. 2019, 41, 1999-2023. 